\title{
Contribution of several nitrogen sources to growth of Alexandrium catenella during blooms in Thau lagoon, southern France
}

\author{
Yves Collos ${ }^{\mathrm{a},}{ }^{*}$, André Vaquer $^{\mathrm{a}}$, Mohamed Laabir ${ }^{\mathrm{a}}$, Eric Abadie ${ }^{\mathrm{b}}$, Thierry Laugier $^{\mathrm{b}}$, Annie \\ Pastoureaud $^{\mathrm{b}}$ and Philippe Souchu ${ }^{\mathrm{b}}$
}

\author{
${ }^{a}$ Laboratoire Ecosystèmes Lagunaires (UMR CNRS 5119), Université Montpellier II, CC093, 34095 Montpellier \\ Cedex 5, France \\ ${ }^{\mathrm{b}}$ Laboratoire Environnement Ressources Languedoc-Roussillon Ifremer, B.P. 171, 34203 Sète, France \\ *: Corresponding author: Y. Collos, Tel.: +33 46714 4744; fax: +33 46714 3719, email address : \\ Yves.Collos@univ-montp2.fr
}

\begin{abstract}
:
A monitoring program with a weekly sampling frequency over a 15-month period indicates that urea concentrations above a certain threshold level may trigger the blooms of Alexandrium catenella in Thau lagoon. However, urea concentrations were also sometimes related to ammonium and dissolved organic nitrogen concentrations, indicating that the role of urea may not be a direct one. An original approach is used to assess the relative contribution of several nitrogen sources (nitrate, nitrite, ammonium, urea) to growth of $A$. catenella by comparing nitrogen uptake rates to nitrogen-based growth rates estimated from dilution experiments during four blooms over a 4-year period (2001-2004) in Thau lagoon. Nitrate and nitrite contributed $0.1-14 \%$ and $0.1-5 \%$ respectively of growth requirements. Ammonium and urea were the main $\mathrm{N}$ sources fueling growth of $A$. catenella $(30-100 \%$ and $2-59 \%$, respectively). Indirect estimates indicated that an unidentified $\mathrm{N}$ source could also contribute significantly to growth at specific times. Concerning ammonium and urea uptake kinetics, half-saturation constants varied between 0.2 and $20 \mu \mathrm{gat} \mathrm{N} \mathrm{L}^{-1}$ for ammonium and between 0.1 and $44 \mu$ gat $\mathrm{N} \mathrm{L}^{-1}$ over the 4-year period, indicating that $A$. catenella can have a competitive advantage over other members of the phytoplankton even under low concentrations of ammonium and urea. However, the observed large changes in ammonium and urea uptake kinetics on a short time scale (days) during blooms preclude more precise estimates of those contributions to growth and require further investigation.
\end{abstract}

Keywords: Alexandrium catenella; HAB; Nitrogen; Growth; Urea; Ammonium; Uptake kinetics 
Introduction

Since 1998, recurrent toxic (Paralytic Shellfish Poisoning) blooms of Alexandrium catenella occur in Thau lagoon (French Mediterranean coast) during spring and/or autumn. They always originate in Angle Creek, a small creek in the north-eastern corner of the lagoon. Nitrogenous nutrients such as urea have been suggested to be important in triggering flagellate blooms (Robert et al., 1986; Glibert and Terlizzi, 1999). However, the relationship may not be a direct one because urea can be degraded to ammonium before being used by phytoplankton. A first study (Collos et al., 2004) indicated a low affinity of A. catenella for nitrogen compounds (nitrate, ammonium, urea) relative to other members of the phytoplankton community and an unbalanced growth following a nutrient pulse with initially high nitrogen accumulation followed by cell division. Here, we report further results from 3 other blooms. We also use an original approach relating nitrogen uptake rates to gross growth rates of $A$. catenella in order to estimate the contribution of each nitrogen compound to vegetative growth and a possible deficit pointing to a nitrogen source other than inorganic nitrogen or urea. The rationale behind this approach is to express both nitrogen uptake rates and growth rates on a common basis : nitrogen. This allows the direct comparison of rates and so the contribution of each nitrogen source to growth can be estimated. Here we test four nitrogen sources (nitrate, nitrite, ammonium, urea) for which ${ }^{15} \mathrm{~N}$ labelled compounds are readily available.

Material and methods

The Thau lagoon is a shallow marine lagoon located on the French Mediterranean coast $\left(43^{\circ} 24^{\prime} \mathrm{N}-3^{\circ} 36^{\prime} \mathrm{E}\right)$ covering $75 \mathrm{~km}^{2}$ (Fig. 1). It has a mean depth of $4 \mathrm{~m}$ with a maximum 
depth of $10 \mathrm{~m}$. The lagoon is connected to the sea by 3 narrow channels. Three oyster farming zones are located along the northwestern shore. The lagoon represent $10 \%$ of French oyster production and is the main oyster production center on the Mediterranean. Since 1998, it has experienced recurrent blooms of Alexandrium catenella that periodically threaten economic activities. Those blooms always originate in Angle Creek, a shallow embayment located on the northeastern part of the lagoon.

From October 1999 to January 2001, along a regular monitoring program for cell counts of A. catenella, we measured urea concentrations on a weekly basis at two stations (Fig. 1): station A5 in Angle Creek (position 4326.916’ N, 00340.300’ E) and station "Bouzigues" (labelled B in Fig. 1) located outside Angle Creek and near the first row of oyster pens (position $43^{\circ} 26.070^{\prime} \mathrm{N}, 003^{\circ} 39.920^{\prime} \mathrm{E}$ ). In 2003, a more extensive sampling program was implemented with weekly sampling for chemical and biological variables (see below) at station A5. During periods of blooms, a grid of 21 stations within Angle Creek was sampled on selected dates for the same variables.

During natural blooms of Alexandrium catenella, uptake kinetics of several $\mathrm{N}$ compounds were studied by the ${ }^{15} \mathrm{~N}$ tracer technique. In parallel, in situ gross and net growth rates as well as grazing rates were determined over $24 \mathrm{~h}$ by the dilution method (Landry and Hassett, 1982). Enrichments were $20 \mu \mathrm{mol}{ }^{15} \mathrm{NH} 4-\mathrm{N} . \mathrm{l}^{-1}$ and all other nutrients in stoichiometric proportions. Surface water was sampled with polycarbonate (PLC) bottles because sampling bottles for which the internal rubber spring had been replaced by silicone tubing still remained toxic to phytoplankton (Collos et al., 2005). A 9 liter sample stored in a 10 liter PLC square bottle was brought back to the laboratory. After gentle stirring, aliquots were withdrawn from this sample and used for various measurements (see below). Cell counts. Cell numbers and chain numbers were determined with a haemocytometer. Cell motility was noted before fixation, using an inverted microscope. 
Nutrients. Nitrate was measured according to Wood et al. (1967), nitrite according to Bendschneider and Robinson (1952) and urea according to Goeyens et al. (1998). Samples for ammonium determination were immediately fixed and measured using the method of Koroleff (1976). For the other nutrients, field samples were brought to the laboratory, stored in acid precleaned PLC carboys. Filtrations and storage of samples were performed within one hour after sampling, in an all glass filtering system through a precombusted $\left(450^{\circ} \mathrm{C}\right.$ for $\left.6 \mathrm{~h}\right)$ Whatman GF/F filter (vacuum $<10 \mathrm{~cm} \mathrm{Hg}$ ). Filtrates were immediately frozen in precombusted Pyrex flasks for later analysis with a segmented flow analyser. Dissolved organic nitrogen (DON) was measured following Armstrong and Tibbits (1968). Particulate matter and isotopic analyses. Samples $(50 \mathrm{ml})$ were filtered on Pall Gelman A/E $13 \mathrm{~mm}$ precombusted filters. There was a linear relationship between PC, PN and volume filtered between 1 and $50 \mathrm{ml}$ (Collos, 2002). Filters were dried at $60^{\circ} \mathrm{C}$ for $24 \mathrm{~h}$, then stored at room temperature. Analyses of particulate carbon, particulate nitrogen, ${ }^{13} \mathrm{C}$ and ${ }^{15} \mathrm{~N}$ content were done on the same sample with a PDZ Europa elemental analysis-mass spectrometry Integra CN system. Calculation of uptake rates were according to Collos (1987), and expressed in units of day ${ }^{-1}$ in order to be compatible with growth rate estimates. Vmax was also expressed on the basis of cell numbers in order to correct for underestimates of uptake due to isotopic dilution of the tracer in the particulate matter by other unlabelled sources (Collos and Slawyk, 1985).

Pigment analyses. Chlorophyll a, b, c and pheopigments a, b and c were measured by spectrofluorometry (Neveux and Lantoine, 1993) on Pall Gelman A/E 13 mm filters. Uptake kinetics. Samples were pre-filtered on a $1000 \mu \mathrm{m}$ mesh, in order to remove major debris (Dupuy et al., 2000), but maintain near natural conditions (Redden et al., 2002) and brought back to the laboratory. $50 \mathrm{ml}$ aliquots were distributed in $60 \mathrm{~mL}$ PLC square bottles and spiked first with a solution of ${ }^{13} \mathrm{C}$ labelled bicarbonate at a constant concentration, then 
with 8 different concentrations and two different ranges (either 0.1 to $10 \mu$ gat $\mathrm{N}^{-1}{ }^{-1}$ or 1 to 100 $\mu$ gat $\mathrm{N}^{-1}$ ) of various $\mathrm{N}$ compounds (nitrate, nitrite, ammonium, urea) and incubated for $1 \mathrm{~h}$. Samples were then processed as above (particulate matter and isotopic analyses).

For determination of kinetic constants, raw data was first inspected visually for biphasic or multiphasic behavior. In case of the latter, only data points corresponding to the first phase were selected to compute the affinity constant $(\mathrm{Ks})$ and the maximum uptake rate (Vmax) with a non linear regression technique.

Net and gross growth rate. A modification of the dilution technique of Landry and Hassett (1982) was used (Collos et al., 2004). A 5\% dilution level was prepared with $0.2 \mu \mathrm{m}$ filtered seawater, and enriched with $\mathrm{h} / 2$ medium (Andersen et al., 2005) with only ammonium as a nitrogen source at a final concentration of $20 \mu$ gat $\mathrm{N}^{-1}$ (H series), along with an undiluted sample, and a control without enrichment (T series). Differential enrichments following Andersen et al. (1991) were also prepared: $\mathrm{h} / 2$ medium without $\mathrm{N}$ and $\mathrm{h} / 2$ medium without $\mathrm{P}$. Incubations were carried out in the laboratory under the same conditions as the cultures. The $5 \%$ sample was considered to be without grazers and this approach is satisfactory when biomass levels are high as in those bloom situations (Dolan et al., 2000). Growth rates were calculated according to Guillard (1973) based on chlorophyll a, chlorophyll c, PC, PN and cell numbers.

Incubations took place in the lab under an irradiance of $100 \mu \mathrm{mol} \cdot \mathrm{m}^{-2} \cdot \mathrm{s}^{-1}$ and $20 \pm 1^{\circ} \mathrm{C} . \mathrm{N}$-based gross growth rates and $\mathrm{N}$ uptake rates were expressed in units of time ${ }^{-1}$. Those values are underestimates of true rates (Collos, 1987), but are nevertheless directly comparable. Nitrogen uptake rates were related to gross growth rates of $A$. catenella in order to estimate the contribution of each $\mathrm{N}$ compound to vegetative growth and the possible deficit pointing to a $\mathrm{N}$ source other than inorganic nitrogen or urea. The contribution of each $\mathrm{N}$ source is the ratio of its uptake rate $\left(\mathrm{d}^{-1}\right)$ to the $\mathrm{N}$-based growth rate $\left(\mathrm{d}^{-1}\right)$. For the unknown source $(\mathrm{X}), \mathrm{N}$ uptake 
rates are summed up and the total is then subtracted from the N-based growth rate. The remaining part is attributed to unknown $\mathrm{N}$ sources.

Results

Out of the 65 samples recovered over the 15 month period (1999-2001), only 5\% exhibited urea concentrations above $0.5 \mu$ gat N.1 ${ }^{-1}$ (Fig. 2). The highest values occurred on 5 June 2000 at station A5 and on 29 May 2000 at station Bouzigues. The relationship shown in Fig. 2 between urea concentration and cell density of A. catenella was obtained with a one week time lag. This was done because there is no instantaneous increase in cell-based growth rate following an increase in limiting substrate concentration for phytoplankton in general (Collos, 1986) and A. catenella in particular (Collos et al., 2004). However the effect of urea may not be a direct one because there were also significant relationships between urea and ammonium during a spatial survey covering the Angle Creek sector at 21 stations (Fig. 3), and between urea and dissolved organic nitrogen (DON) during a time series over 6 months at station A5 (Fig. 4). Urea represented between 3 and 25\% of dissolved organic nitrogen in Angle Creek over a six month period with weekly sampling.

A summary of biomass estimates during A. catenella blooms (Table 1) indicates that cell densities ranged over almost two orders of magnitude, while there were less variations in chlorophylls and particulate carbon and nitrogen. A. catenella represented between 62 (October 2001) and $99 \%$ (November 2001) of total cell numbers, the percentage varying between 83 and $92 \%$ at the other dates. 
Gross growth rates calculated on the basis of changes in cell numbers, chlorophyll a, and particulate nitrogen (PN) are presented in Table 2. The cell-based growth rate ranged between -0.12 and $0.89 \mathrm{~d}^{-1}$ and was related neither to the other growth estimates nor to the grazing rates for the whole data set. However, if the November 2004 data point was removed, the relationship between cell-based growth rates and grazing rates became significant $(\mathrm{p}<0.05)$, and the slope (1.5) indicated that grazing was generally greater than gross growth. The Chl a-based growth and grazing rates were related in a significant $(\mathrm{p}<0.05)$ way and the slope (0.94) indicated that both processes were in balance. The PN-based and Chl a-based growth rates were related significantly to each other $\left(r^{2}=0.712, p<0.05\right)$. Chl a-based growth rates were generally higher than cell-based growth rate (2 to 10x) excepted in October 2003 when both rates were negative and in November 2004 when the highest cell-based growth rates ever reported for $A$. catenella, corresponding to 1.1 to 1.3 divisions per day were recorded. At that time, balanced growth seem to have been achieved over $24 \mathrm{~h}$.

In unenriched controls, cell-based growth rates were very low or negative, and were not related to rates in enriched samples. Differential enrichments indicated primary $\mathrm{N}$ limitation (all samples enriched with medium without $\mathrm{N}$ exhibited negative growth rates, except in November 2004 with a low value of $0.16 \mathrm{~d}^{-1}$ ) and secondary P limitation (samples enriched with medium without $\mathrm{P}$ exhibited growth rates between 18 and $100 \%$ of the controls with full enrichment. Chla-based growth in unenriched samples were significantly correlated to those in enriched samples but rates were reduced by about half.

Uptake kinetics were measured during each bloom (Fig. 5) and used to calculate uptake rates at in situ concentrations. Those values, when compared to growth estimates based on nitrogen as a biomass index (Table 2), allow to estimate the contribution of each $\mathrm{N}$ compound to growth of A. catenella (Table 3). From those values, nitrate and nitrite are minor substrates for growth, while ammonium and urea supply most of the nitrogen needed. Indirect 
estimates also indicate a sometimes important (up to 67\%) contribution of another $\mathrm{N}$ compound that is neither nitrate, nitrite, ammonium or urea.

Concerning ammonium and urea uptake kinetics, half-saturation constants varied between 0.2 and $20 \mu$ gat N. $1^{-1}$ for ammonium and between 0.1 and $44 \mu$ gat N. $1^{-1}$ over the four year period. Over smaller time scales (days), a large variability in uptake parameters was sometimes observed (Fig. 6). This occurred during the development of a bloom of $A$. catenella, with the biomass being multiplied by ten over 3 days in terms of cell numbers $(0.7$ vs. 10.1 millions cells..$\left.^{-1}\right)$ as well as chl a (17.4 vs $\left.150 \mu \mathrm{g} . \mathrm{l}^{-1}\right)$. Vmax values were similar in absolute (per cells) or specific (per unit $\mathrm{N}$ ) rates but Ks varied over an order of magnitude $(0.5$ and $6.2 \mu$ gat N. ${ }^{-1}$ ) over the same three days. The increases in ammonium uptake with ammonium concentrations in those experiments were accompanied by decreases in inorganic carbon fixation (Fig. 6) but the ranges of $\mathrm{C} / \mathrm{N}$ uptake ratios differed markedly between dates. They ranged from 10 to $60 \mathrm{~mol} \mathrm{C} / \mathrm{mol} \mathrm{N}$ initially, and from 20 to $1300 \mathrm{~mol} \mathrm{C} / \mathrm{mol} \mathrm{N}$ three days later, reflecting a greater contribution of another $\mathrm{N}$ source as the bloom developed. During the same period, the $\mathrm{C} / \mathrm{N}$ composition ratios did not change markedly (7.8 vs $7.2 \mathrm{~mol}$ $\mathrm{C} / \mathrm{mol} \mathrm{N}$ ). The cell-based and PN-based growth rates both decreased by a factor of about 2 over the 3 day period (26-29 September 2003). Initial pheophytin a/chlorophyll a ( $\mathrm{Pa} / \mathrm{Ca})$ ratios ranged from 0.07 (November 2001) to 0.23 (October 2001). After $24 \mathrm{~h}$ incubations, the final $\mathrm{Pa} / \mathrm{Ca}$ ratios ranged from 0.06 to 0.26 .

\section{Discussion}

The results of the monitoring program over a one year period (Fig. 2) suggest a threshold effect (0.5 to $1.5 \mu$ gat N. $\left.{ }^{-1}\right)$ similar to that described by Glibert and Terlizzi (1999) in aquaculture ponds, excepted for the one week time lag that was introduced following the 
assumption that the growth response of $A$. catenella to an increase in urea is not instantaneous. The importance of urea relative to the total DON pool (3-25\%) is higher than the average value mentioned in a recent review (Bronk, 2002), but lower than in the Chesapeake Bay (Glibert et al. 2006). It is in the same range as that reported by Mitamura and Saijo (1975) in a shallow eutrophic bay. This suggests the potential importance of urea in such environments. Although the relationship in Fig. 2 is striking in its similarity with results from Glibert and Terlizzi (1999), its interpretation is not easy for at least two reasons. The first one is that a concentration is the result of two processes: production and consumption. The second one is illustrated by the relationship between urea and other components of the dissolved N pool (Fig. 3 and 4). This indicates that the effect of urea may not be a direct one. In order to further explore those relationships, we measured rates of uptake and growth based on a common unit : nitrogen. As mentioned in the methods section, both rates are underestimated (Collos, 1987), but the significant relationship between PN-based and Chl abased growth rates indicates that most of the changes in PN are due to A. catenella, and the slope of the regression indicates that PN-based growth rates are underestimated by about $33 \%$. Our approach involves a number of assumptions and calculations that introduce uncertainty in the final estimates. The « real » values probably lie between those of the $\mathrm{H}$ and T series shown in Table 3 because the $\mathrm{H}$ series overestimate growth rates due to enrichment and the $\mathrm{T}$ series underestimate growth rates because there was no enrichment. But the main cause of variability in such estimates seems to come from the short term changes in uptake kinetics such as those described in Fig. 5.

Concerning ammonium uptake kinetics, the two extreme Ks values (0.5 and $6.2 \mu$ gat $\mathrm{N} . \mathrm{l}^{-1}$ ) found here over a 3 day interval are lower than the value of $8.4 \mu$ gat N..$^{-1}$ previously found during the November 2001 bloom (Collos et al., 2004). Possibly the changes and decreases in growth between September 26 and 29, 2003 were due to light limitation because 


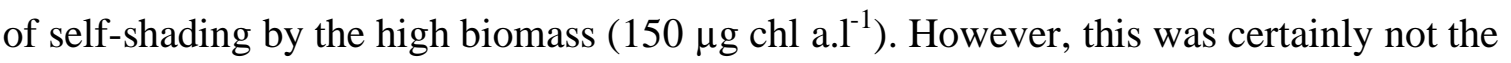
case in November 2004 when a similar biomass $\left(143.5 \mu \mathrm{g}\right.$ chl a. $\left.{ }^{-1}\right)$ was observed, yet the highest cell-based growth rate ever reported for A. catenella was recorded simultaneously (Table 2).

Harrison (1976) also observed large differences in Ks for natural populations of the dinoflagellate Gonyaulax polyedra sampled at different times and interpreted these as reflecting differences in the physiological condition of the organisms. In our case, the ten fold increase in $\mathrm{KNH}_{4}$ over 3 days was accompanied by a 2 fold decrease in cell-based growth rate. During the same period, the $\mathrm{Pa} / \mathrm{Ca}$ ratio decreased from 0.17 to 0.10 . In October 2003, the negative growth rate was accompanied by a $\mathrm{Pa} / \mathrm{Ca}$ ratio of 0.11 . For healthy phytoplankton, values of the $\mathrm{Pa} / \mathrm{Ca}$ ratio range from 0.05 to 0.10 (Shuman and Lorenzen, 1975; Barlow et al., 1993; Fundel et al., 1998). So the low or negative growth rates do not seem to be due to degradation of photosystem II. The simultaneous occurrence of negative growth rates and low $\mathrm{Pa} / \mathrm{Ca}$ ratios was also observed in cultures of $A$. catenella and may reflect encystment or gametogenesis in response to an environmental stress (Collos et al., 2006).

The maximal cell-based gross growth rate reported here $\left(0.89 \mathrm{~d}^{-1}\right)$ is $62 \%$ higher than the maxima of $0.50-0.55 \mathrm{~d}^{-1}$ measured so far in laboratory cultures for A. catenella (Matsuda et al., 1999; Doblin et al., 2000; Collos et al., 2004). Using the dilution technique with natural populations, Garcés et al. (2005) reported gross cell-based growth rates of A. catenella between 0.24 and $0.44 \mathrm{~d}^{-1}$ in Tarragona harbor, with apparently no nutrient limitation. This lack of nutrient limitation contrasts with our results but is probably due to the higher nutrient levels than in Thau lagoon. Typically, DIN levels in blooms were always below $10 \mu$ gat N.1 ${ }^{-1}$ in Angle Creek while they could reach $60 \mu$ gat N.1 ${ }^{-1}$ in Tarragona harbour. Garcés et al. (2005) also reported generally higher (3 to 5 times) chla-based growth rates than cell-based 
growth rates on the $24 \mathrm{~h}$ time scale which confirms our previous (Collos et al. 2004) and present results concerning the time lag between $\mathrm{N}$ uptake, chla synthesis and cell division. The very large difference (10x) between chla-based growth rates and cell-based growth rates in October 2001 is probably due to the lower contribution of A. catenella (62\%) to the total phytoplankton. In fact, removing the 25 October 2001 data point actually improves the relationship between the chla -based growth rate and chla-based grazing rate and the relationship between PN-based growth and chla-based growth, $\mathrm{p}$ values becoming less than 0.01 for both.

A close relationship between cell based and chla based growth rates is not to be expected because of the varying chla cell content (Carlsson et al., 1998, Carignan et al., 2002). The only exception was the November 2004 bloom where balanced growth appears to have been achieved, and a possible cause for the highest growth rate ever reported for this organism $\left(1.3\right.$ div. $\left.\mathrm{d}^{-1}\right)$. Those rates were obtained under artificial light in the laboratory and are lower than growth rates of other dinoflagellates incubated under natural light (Smayda, 1996). Still, the higher growth rates obtained in the field compared to laboratory cultures point out to a lack of some growth factor in culture media used so far for A. catenella. Concerning the unknown $\mathrm{N}$ source identified by indirect means, it could be DON such as humic acids (Carlsson et al., 1998) or PN such as cyanobacteria of the genus Synechococcus which has recently been shown to be grazed by A. catenella (Jeong et al., 2005).

Our results also show that $A$. catenella can have a competitive advantage over other members of the phytoplankton even under low concentrations of ammonium and urea.

The main challenge now remaining is to better constrain the uptake values as there are rapid changes in ammonium uptake kinetics on short time scales, introducing a large variability in calculations of uptake values. Interactions between ammonium and urea also have to be studied in order to better define the role of urea in the growth 
of A. catenella. In phytoplankton, such interactions appear to be complex and both species and nutrient state dependent (Waser et al., 1998). Data available from the present study indicate an inhibition of urea uptake by ammonium concentrations above $0.2 \mu$ gat N.L ${ }^{-1}$, but this phenomenon clearly requires further investigation in simpler systems such as laboratory cultures because processes such as ammonium excretion during ammonium assimilation (Uchida, 1976; Price and Harrison, 1988) complicates the relationship.

\section{References}

Andersen, R.A., Berges, J.A., Harrison, P.J., Watanabe, M.M., 2005. Recipes for freshwater and seawater media. In: Andersen, R.A. (Ed.), Algal culturing techniques, Elsevier, Amsterdam, pp. 429-538.

Andersen, T., Schartau, A.K.L., Paasche, E., 1991. Quantifying external and internal nitrogen and phosphorus pools, as well as nitrogen and phosphorus supplied through remineralization, in coastal marine plankton by means of a dilution technique. Mar. Ecol. Prog. Ser. 69, 67-80.

Armstrong, F.A.J., Tibbits, S., 1968. Photochemical combustion of organic matter in sea water for nitrogen, phosphorus and carbon determination. J. Mar. Biol. Ass. UK 48, 143-152.

Barlow, R.G., Mantoura, R.F.C., Gough, M. A., Fileman, T. W., 1993. Pigment signatures of the phytoplankton composition in the Northeastern Atlantic during the 1990 spring bloom. Deep-Sea Res. Part II 40, 459-477.

Bendschneider, K., Robinson, R.J., 1952. A new spectrophotometric method for the determination of nitrite in seawater. J. Mar. Res. 11, 87-96.

Bronk, D.A., 2002. Dynamics of DON. In: Hansell, D.A., Carlson C.A. (Eds.), Biogeochemistry of marine dissolved organic matter. Academic Press, Amsterdam, 
pp. $153-247$.

Carignan, M.O., Montoya, N.G., Carreto, J.I., 2002. Long-term effects of ultraviolet radiation on the composition of pigment and mycosporine-like amino acids (MAAs) composition in Alexandrium catenella. In : Arzul, G. (Ed.), Aquaculture, environment and marine phytoplankton, Actes Colloq. IFREMER 34, pp. 191-207.

Carlsson, P., Edling, H., Béchemin, C., 1998. Interactions between a marine dinoflagellate (Alexandrium catenella) and a bacterial community utilizing riverine humic substances. Aquat. Microb. Ecol. 16, 65-80.

Collos, Y., 1986. Time-lag algal growth dynamics: biological constraints on primary production in aquatic environments. Mar. Ecol. Progr. Ser. 33, 193-206.

Collos, Y., 1987. Calculations of ${ }^{15} \mathrm{~N}$ uptake rates by phytoplankton assimilating one or several nitrogen sources. Appl. Radiat. Isot. 38, 275-282.

Collos, Y., 2002. Determination of particulate carbon and nitrogen in coastal waters. In: Subba Rao, D.V. (Ed.), Pelagic Ecology Methodology, Balkema (The Netherlands), pp. 333-341.

Collos, Y., Gagne, C., Laabir, M., Vaquer, A., Cecchi, P., Souchu, P., 2004. Nitrogenous nutrition of Alexandrium catenella (Dinophyceae) in cultures and in Thau lagoon, southern France. J. Phycol. 40, 96-103.

Collos, Y., Husseini-Ratrema, J., Bec, B., Vaquer, A., Lam Hoai, T., Rougier, C., Pons, V., Souchu, P. 2005. Pheopigment dynamics, zooplankton grazing rates and the autumnal ammonium peak in a Mediterranean lagoon. Hydrobiol. 550, 83-93.

Collos, Y., Slawyk, G., 1985. On the compatibility of carbon uptake rates calculated from stable and radioactive isotope data: implications for the design of experimental protocols in aquatic primary productivity. J. Plankton Res. 7, 595-603.

Collos, Y., Lespilette, M, Vaquer, A., Laabir, M., Pastoureaud, A. 2006. Uptake and 
accumulation of ammonium by Alexandrium catenella during nutrient pulses. Afr. J. Mar. Sci. 28, 313-318.

Doblin, M., Legrand, C., Carlsson, P., Hummert, C., Granéli, E., Hallegraeff, G., 2001. Uptake of humic substances by the toxic dinoflagellates Alexandrium catenella. In: Hallegraeff, G.M., Blackburn, S.I., Bolch, C.J., Lewis, R.J. (Eds.) Harmful algal blooms 2000. UNESCO, Paris, pp. 336-339.

Dolan, J.R., Gallegos, C.L., Moigis, A., 2000. Dilution effects on microzooplankton in dilution grazing experiments. Mar. Ecol. Prog. Ser. 200, 127-139.

Dupuy, C., Vaquer, A., Lam-Höai, T., Rougier, C., Mazouni, N., Lautier, J., Collos, Y., Le Gall, S., 2000. Feeding rate of the oyster Crassostrea gigas in a natural planktonic community of the Mediterranean Thau Lagoon. Mar. Ecol. Prog. Ser. 205, 171-184.

Fundel, B., Stich, H.B., Schmid, H., Maier, G., 1998. Can phaeopigments be used as markers for Daphnia grazing in Lake Constance ? J. Plankton Res. 20, 1449-1462.

Garcés, E., Vila, M., Maso, M., Sampedro, N., Giacobbe, M.G., Penna, A., 2005. Taxonspecific analysis of growth and mortality rates of harmful dinoflagellates during bloom conditions. Mar. Ecol. Prog. Ser. 301, 67-79.

Glibert, P.M., Harrison, J., Heil, C., Seitzinger, S., 2006. Escalating worlwide use of urea - a global change contributing to coastal eutrophication. Biogeochem. 77, 441-463.

Glibert, P.M., Terlizzi, D.E., 1999. Cooccurrence of elevated urea levels and dinoflagellate blooms in temperate estuarine aquaculture ponds. Appl. Env. Microbiol. $65,5594-5596$.

Goeyens, L., Kindermans, N., Abu Yusuf, M., Elskens, M., 1998. A room temperature procedure for the manual determination of urea in seawater. Estuar. Coast. Shelf Sci. 47, 415-418.

Guillard, R.R.L., 1973. Division rates. In: Stein, J.R. (Ed.) Handbook of phycological 
methods. Culture methods and growth measurements. Cambridge University Press, Cambridge, pp. 289-311.

Harrison, W. G. 1976. Nitrate metabolism of the red tide dinoflagellate Gonyaulax polyedra. J. Exp. Mar. Biol. Ecol. 21, 199-209.

Jeong, H.J., Park, J.Y., Nho, J.H., Park, M.O., Ha, J.H., Seong, K.A., Jeng, C., Seong, C.N., Lee, K.Y., Yih, W.H., 2005. Feeding by red-tide dinoflagellates on the cyanobacterium Synechococcus. Aquat. Microb. Ecol. 41 (2), 131-143.

Koroleff, F., 1976. Determination of nutrients. In: Grasshoff, K. (Ed.), Methods of Seawater analysis. Verlag Chemie, Weinheim, pp. 117-182

Landry, M.R., Hassett, R.P., 1982. Estimating the grazing impact of marine micro-zooplankton. Mar. Biol. 67, 283-288.

Matsuda, A., Nishijima, T., Fukami, K., 1999. Effects of nitrogenous and phosphorus nutrients on the growth of toxic dinoflagellate Alexandrium catenella. Nippon Suisan Gakkaishi 65, 847-855.

Mitamura, O., Saijo, Y., 1975. Decomposition of urea associated with photosynthesis of phytoplankton in coastal waters. Mar. Biol. 30, 67-72.

Neveux, J., Lantoine, F., 1993. Spectrofluorometric assay of chlorophylls and phaeopigments using the least squares approximation technique. Deep-Sea Res. 40, 1747-1765.

Price, N.M., Harrison, P.J., 1988. Uptake of urea C and urea $\mathrm{N}$ by the cosatl marine diatom Thalassiosira pseudonana. Limnol. Oceanogr. 33, 528-537.

Redden, A.M., Sanderson, B.G., Rissik, D., 2002. Extending the analysis of the dilution method to obtain the phytoplankton concentration at which microzooplankton grazing becomes saturated. Mar. Ecol. Prog. Ser. 226, 27-33.

Robert, J.M., Vincendeau, M.L., Maestrini, S.Y., Marion, A., 1986. Prises simultanées de l'azote minéral et de l'urée par les algues unicellulaires des claires ostréicoles: effet de 
la source d'azote sur la nature du peuplement. C. R. Acad. Sci. (Paris) 303, 167-170.

Shuman, F.R., Lorenzen, C.J., 1975. Quantitative degradation of chlorophyll by a marine herbivore. Limnol. Oceanogr. 20, 580-586.

Smayda, T.J., 1996. Dinoflagellate bloom cycles: what is the role of cellular growth rate and bacteria ? In: Yasumoto, T., Oshima, Y., Fukuyo, Y. (Eds.), Harmful and toxic algal blooms. Intergovernmental Oceanographic Commission of UNESCO, pp. 331-334.

Uchida, T., 1976. Excretion of ammonia by Prorocentrum micans Ehrenberg in urea-grown culture. Jap. J. Ecol. 26, 43-44.

Waser, N.A, Yin, K.D., Yu, Z.M., Tada, K., Harrison, P.J., Turpin, D.H., Calvert, S.E., 1998. Nitrogen isotope fractionation during nitrate, ammonium and urea uptake by marine diatoms and coccolithophores under various conditions of $\mathrm{N}$ availability. Mar. Ecol. Progr. Ser. 169, 29-41.

Wood, E.D., Armstrong, F.A.J., Richard, F. A., 1967. Determination of nitrate in sea water by cadmium copper-reduction to nitrite. J. Mar. Biol. Assn. U.K. 47, 23-31. 
Table 1. Description of Alexandrium catenella blooms in Angle Creek

Chl : chlorophyll ; PC : particulate carbon ; PN : particulate nitrogen

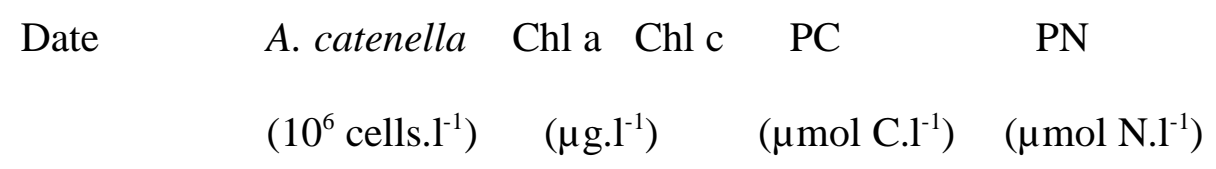

$\begin{array}{llllll}\text { 25 Oct. 01 } & 0.23 & 9.9 & 1.1 & 64.9 & 9.0 \\ \text { 6 Nov 01 } & 2.5 & 44.5 & 7.0 & 414.0 & 34.0 \\ \text { 26 Sept. 03 } & 0.5 & 17.4 & 1.1 & 177.5 & 18.1 \\ \text { 27 Sept. 03 } & 1.2 & 33.5 & 2.4 & 295.8 & 23.4 \\ \text { 30 Sept. 03 } & 10.5 & 150.0 & 12.9 & 679.7 & 87.7 \\ \text { 1 Oct. 03 } & 20,2 & 250.4 & 20,7 & 1487.0 & 164.6 \\ \text { 5 Nov. 04 } & 4.6 & 143.5 & 14.0 & 495.0 & 70.7\end{array}$


Table 2. Gross growth rates of $A$. catenella estimated by the dilution technique over 24 hours and using different biomass estimates.

PN: particulate nitrogen, G: grazing

\begin{tabular}{|c|c|c|c|c|}
\hline Date & $\begin{array}{l}\text { Cell- } \mu \text { max } \\
\left(d^{-1}\right)\end{array}$ & $\begin{array}{l}\text { Chla- } \mu \text { max } \\
\left(d^{-1}\right)\end{array}$ & $\begin{array}{l}\mathrm{PN}-\mu \max \\
\left(\mathrm{d}^{-1}\right)\end{array}$ & $\begin{array}{l}\text { cell-G } \\
\left(\mathrm{d}^{-1}\right)\end{array}$ \\
\hline 25 Oct. 2001 & 0.11 & 1.59 & 0.44 & 0.00 \\
\hline 6 Nov. 2001 & 0.33 & 1.95 & 1.68 & 0.29 \\
\hline 26 Sept. 2003 & 0.43 & 1.53 & 0.58 & 0.28 \\
\hline 27 Sept. 2003 & 0.80 & 2.52 & 1.86 & 1.40 \\
\hline 30 Sept. 2003 & 0.37 & 0.62 & 0.76 & 0.41 \\
\hline 1 Oct. 2003 & -0.12 & -0.07 & -0.12 & 0.00 \\
\hline 5 Nov. 2004 & 0.89 & 0.78 & 0.49 & 0.37 \\
\hline
\end{tabular}


Table 3. Contribution of known and unknown nitrogen sources to PN-based growth of $A$. catenella during blooms. Range of values from 6 series of measurements over 3 years.

In the $\mathrm{H}$ series with full enrichment, the contribution of $\mathrm{NH}_{4}$ corresponds to $20 \mu \mathrm{mol} \mathrm{N} . \mathrm{l}^{-1}$ and other $\mathrm{N}$ sources at in situ concentrations. In the $\mathrm{T}$ series without any enrichment, the contributions of all known $\mathrm{N}$ sources correspond to in situ concentrations.

$\begin{array}{lll}\text { N source } & \begin{array}{l}\% \text { total } \mathrm{H} \\ \text { growth }\end{array} & \text { growth } \\ & & \\ & 0.1-3 & 5-14 \\ \text { Nitrate } & 0.1-1 & 1-5 \\ \text { Nitrite } & 30-68 & 32-100 \\ \text { Ammonium } & 2-36 & 48-59 \\ \text { Urea } & 0-67 & 0-13\end{array}$


Figure captions

1. Study site and station locations (A5 and B). Urban areas in black, shellfish farming areas in grey.

2. Relationship between urea concentrations and cell densities of A. catenella at two stations in Thau lagoon over a 15 month period.

3. Relationship between urea and ammonium concentrations during a spatial survey of Angle Creek

4. Relationship between dissolved organic nitrogen (minus urea) and urea concentration at one station in Angle Creek over a six month period.

5. Representative relationship between specific uptake rates of several nitrogen compounds and concentrations in Angle Creek during a bloom of A. catenella.

6. Short-term changes in ammonium uptake $\left(\mathrm{VNH}_{4}\right)$ kinetics and inorganic carbon fixation (VDIC) during a bloom of $A$. catenella in Angle Creek. Diamonds : ammonium uptake on 26 September 2003 ; small squares : ammonium uptake on 29 September 2003 ; triangles : carbon fixation on 26 September 2003 ; large squares : carbon fixation on 29 September 2003. 


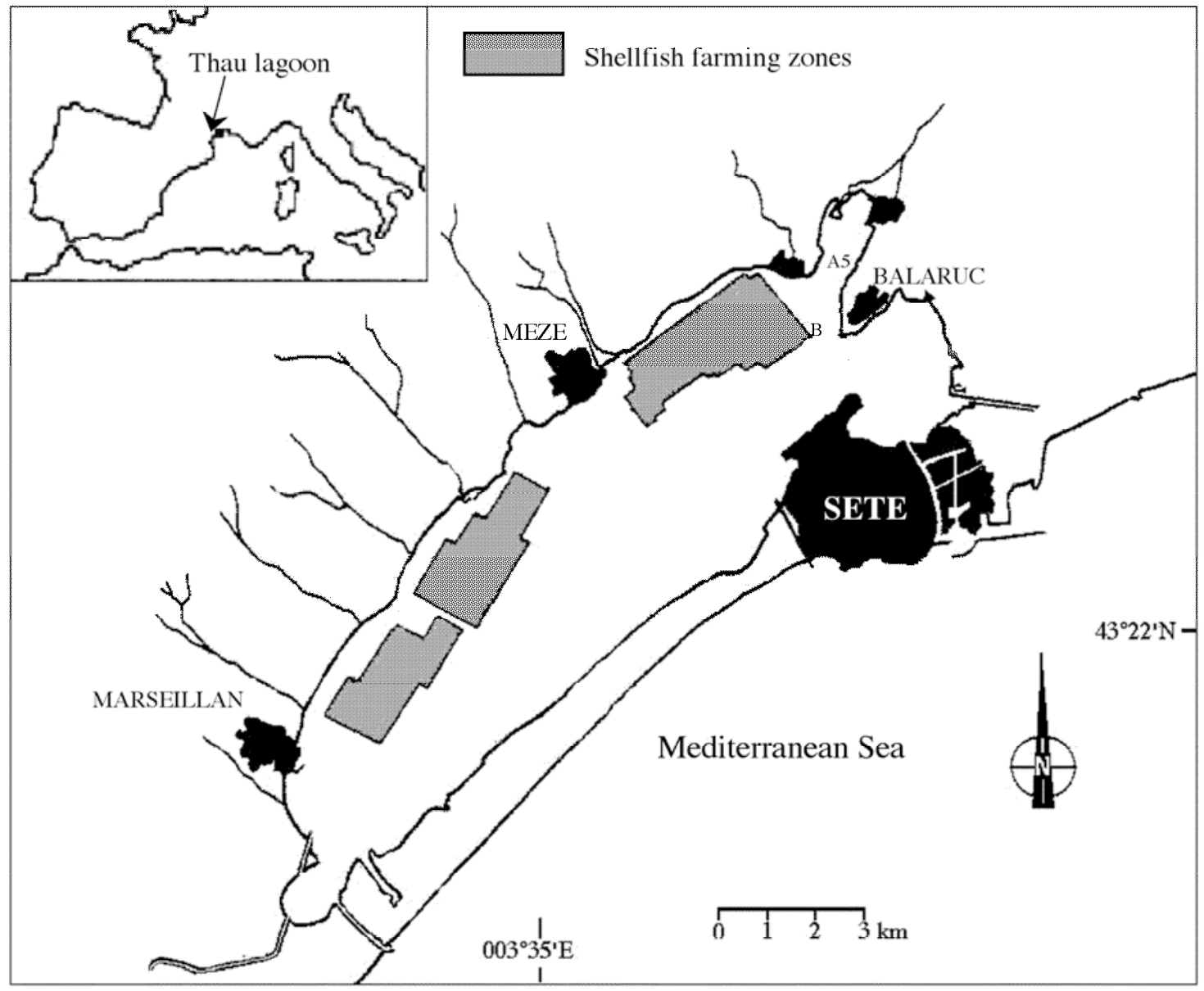

Figure 1 


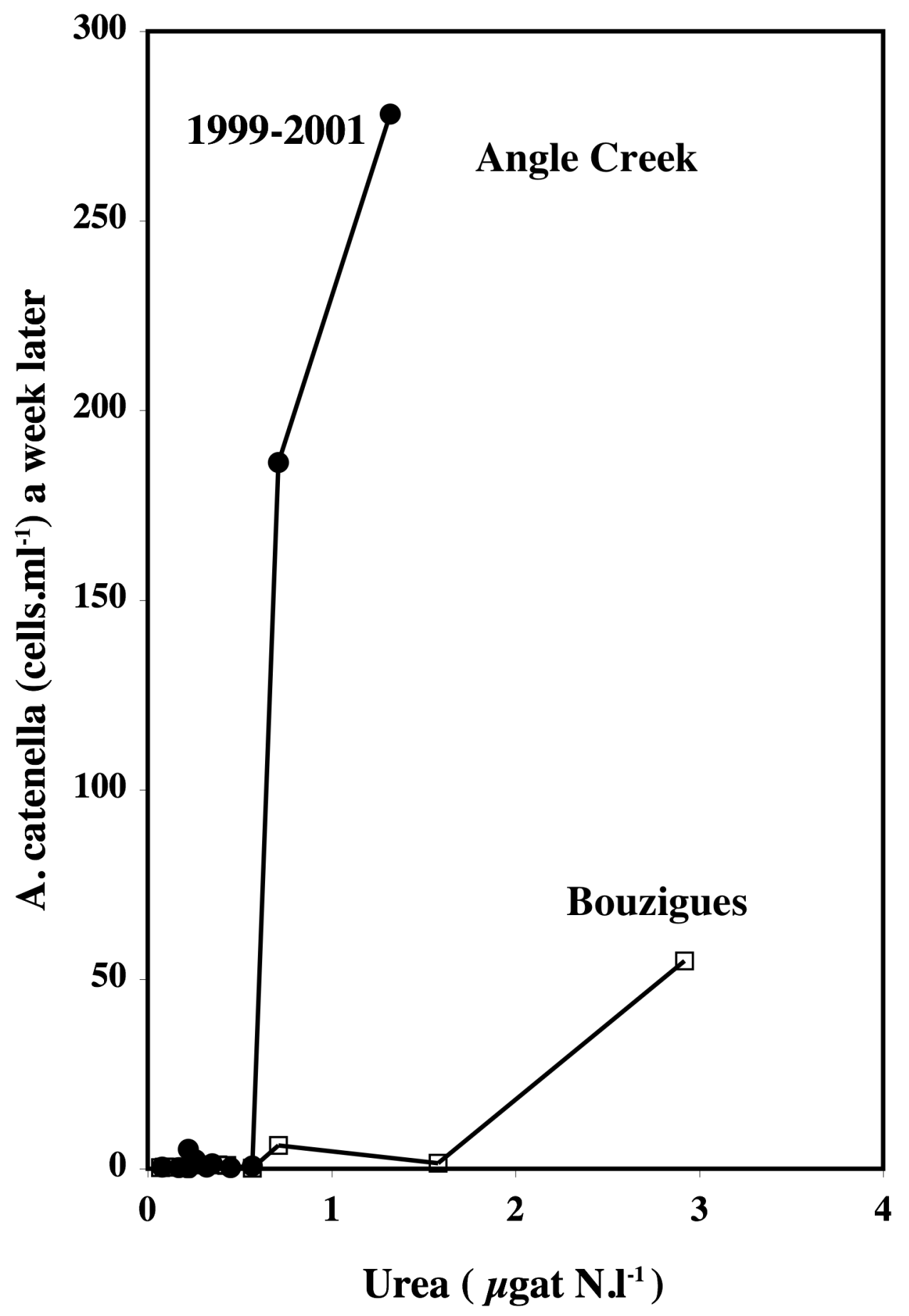

Figure 2 


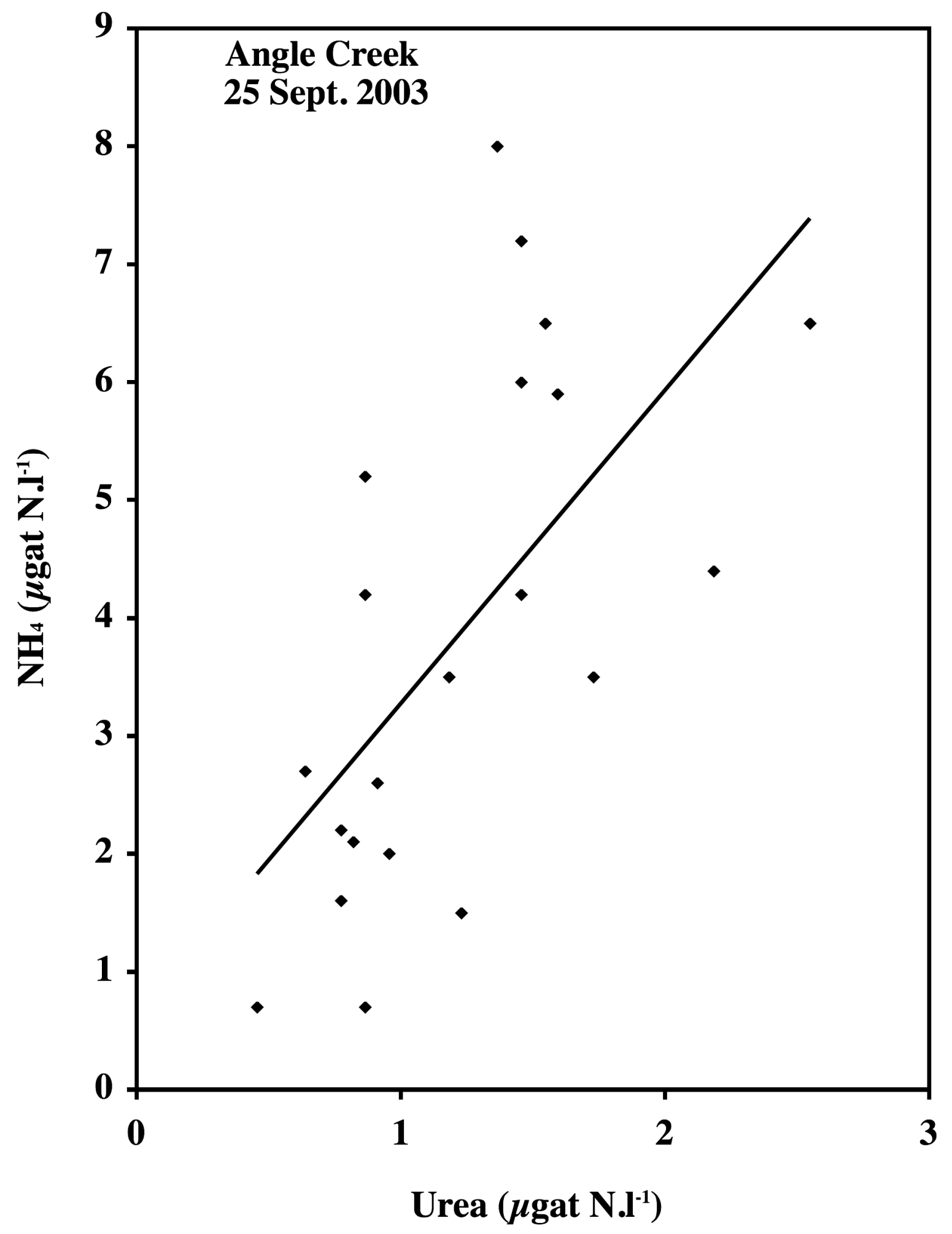

Figure 3 


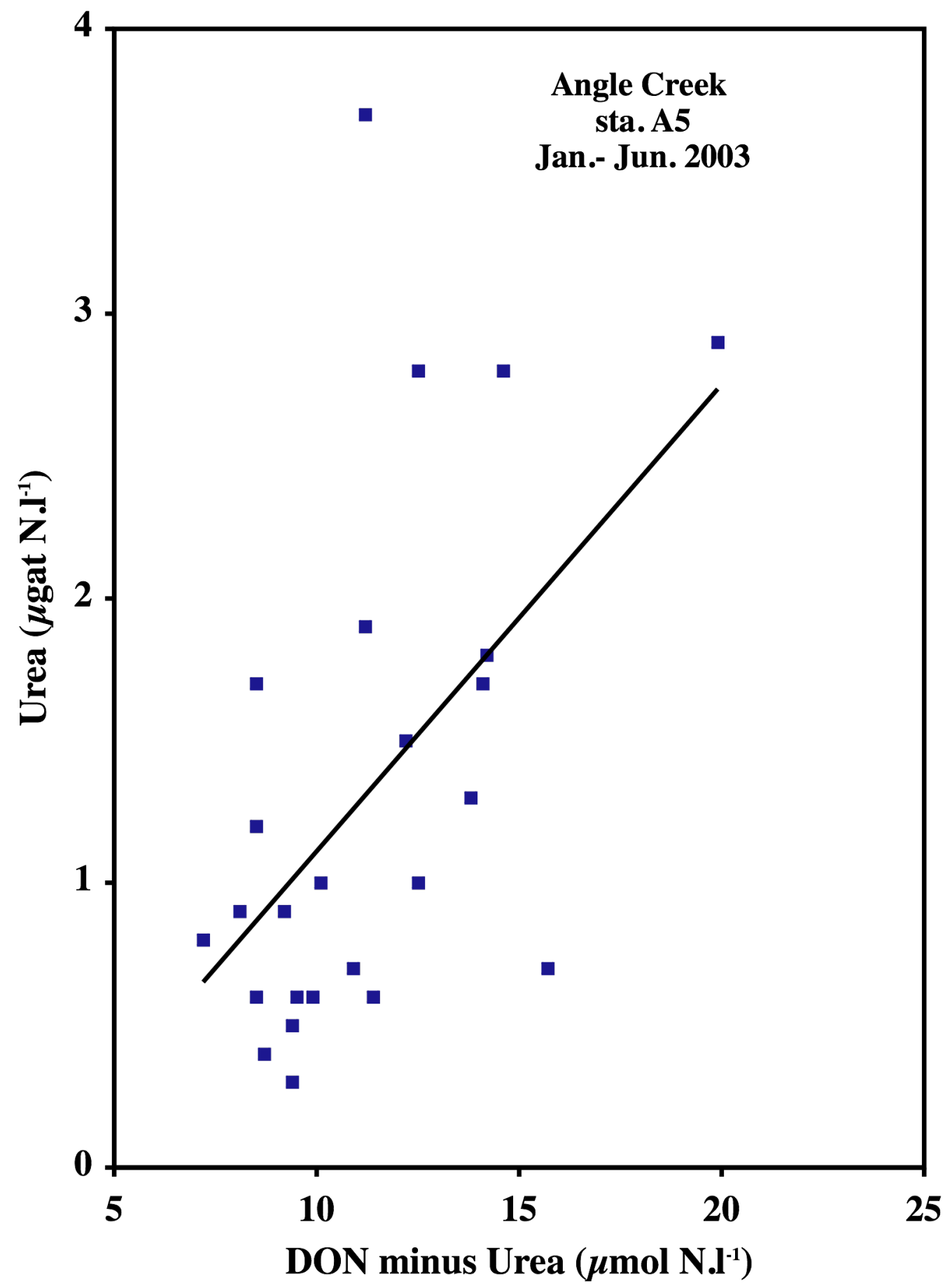

Figure 4 


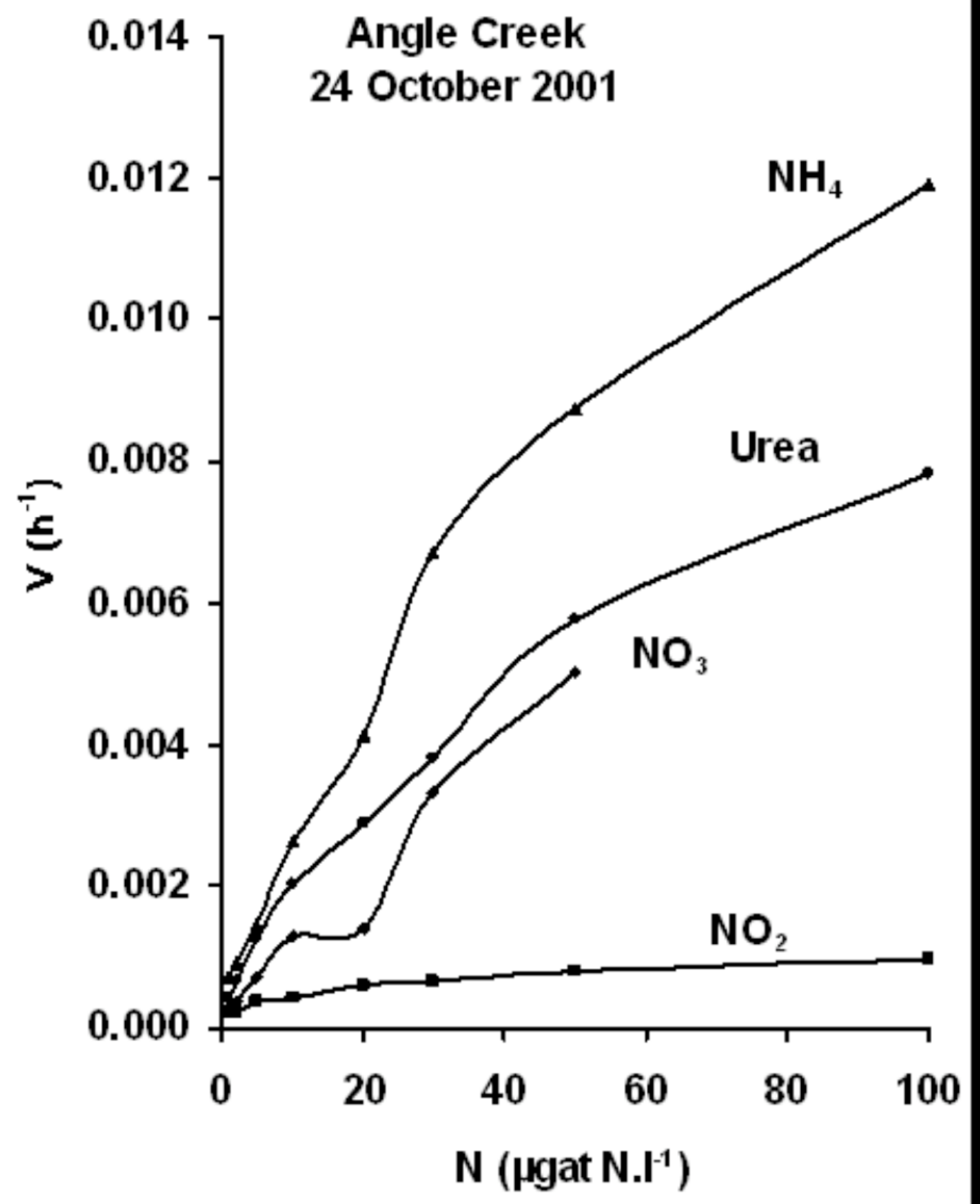

Figure 5 


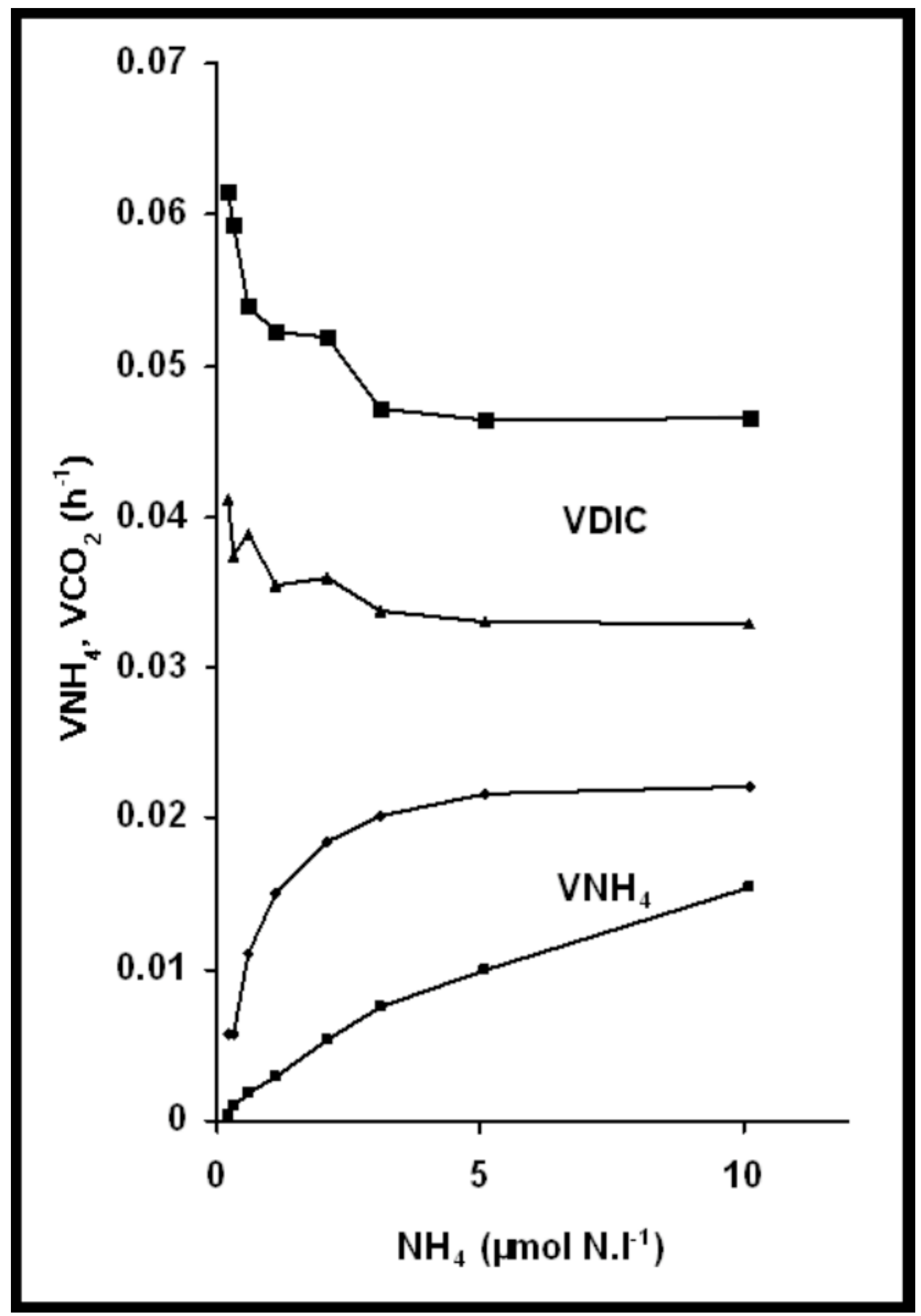

Figure 6 